\title{
Xanthoria parietina as a biomonitor of airborne heavy metal pollution in forest sites in the North East of Morocco
}

\author{
Ghita El Rhzaoui ${ }^{1}$, Pradeep K. Divakar ${ }^{2}$, Ana Crespo², \\ Hikmat Tahiri' ${ }^{1}$ \& Fatima Ezzahra El Alaoui-Faris ${ }^{1}$
}

\begin{abstract}
El Rhzaoui G., Divakar, P.K., Crespo, A., Tahiri, H. \& El Alaoui-Faris, F.E. Xanthoria parietina as a biomonitor of airborne heavy metal pollution in forest sites in the North East of Morocco. Lazaroa 36: 13-41 (2015).

Xanthoria parietina, common foliose lichen, growing in its natural habitat, was analysed for the concentration of five heavy metals (Fe, $\mathrm{Cr}, \mathrm{Zn}, \mathrm{Pb}$ and $\mathrm{Cu}$ ) from different forest sites of North East of Morocco (Kenitra, Sidi Boughaba, Mkhinza, Ceinture Verte near Temara city, Skhirat, Bouznika and Mohammedia). The quantification was carried out by inductively coupled plasma - atomic emission spectrometry (ICP-AES). Results were highly significant $p<0,001$. The concentration of metals is correlated with the vehicular activity and urbanization. The total metal concentration is highest at the Kenitra area, followed by Ceinture Verte site near Temara city, which experience heavy traffic throughout the year. Scanning electron microscopy (SEM) of particulate matter on lichen of Xanthoria parietina was assessed as a complementary technique to wet chemical analysis for source apportionment of airborne contaminant. Analysis revealed high level of $\mathrm{Cu}, \mathrm{Cr}$, $\mathrm{Zn}$ and $\mathrm{Pb}$ in samples near roads.
\end{abstract}

Keywords: Biomonitorización air contamination, inductively coupled plasma, atomic emission spectrometry, Scanning Electron Microscopy.

Resumen: El Rhzaoui G., Divakar, P.K., Crespo, A., Tahiri, H. \& El Alaoui-Faris, F.E. Xanthoria parietina como biomonitor de contaminación por metales pesados en el aire en bosques del nordeste de Marruecos. Lazaroa 36: 31-41 (2015).

Se ha realizado el análisis sobre la concentración de cinco metales pesados ( $\mathrm{Fe}, \mathrm{Cr}, \mathrm{Zn}, \mathrm{Pb}$ y $\mathrm{Cu}$ ) en talos de Xanthoria parietina, líquen folioso común que crece en distintos bosques del noreste de Marruecos (Kenitra, Sidi Boughaba, Mkhinza, ciudad Ceinture Verte cerca de Temara, Skhirat, Bouznika y Mohammedia). La cuantificación se llevó a cabo por plasma de acoplamiento inductivo - espectrometría de emisión atómica (ICP-AES). Los resultados fueron altamente significativos $\mathrm{p}<0.001$. La concentración de metales se correlaciona con la actividad motora y la cercanía de núcleos urbanos. La concentración total de metal es más alta en la zona de Kenitra, seguido de Ceinture Verte sitio cerca de la ciudad de Temara, que experimenta el tráfico pesado durante todo el año. La microscopía electrónica de barrido (SEM) de material particulado sobre líquenes de Xanthoria parietina se evaluó como una técnica cualitativa omplementaria al análisis químico para estimar la cantidad de contaminantes en el aire. El análisis reveló alto nivel de $\mathrm{Cu}, \mathrm{Cr}, \mathrm{Zn}$ y $\mathrm{Pb}$ en muestras cerca de las carreteras.

Palabras clave: Biomonitorización de la contaminación del aire, plasma acoplado inductivamente, espectrometría de emisión atómica, microscopía electrónica de barrido.

\section{INTRODUCTION}

Lichens are very effective as an early warning system to detect environmental changes (MARKERT \& al., 1996). As perennial, slow growing organisms, most lichen species maintain a fairly uniform morphology with time and accumulation occurs throughout the year with passive ion exchange properties (TYLER, 1989). Lichens are widely used in biomonitoring stud-

\footnotetext{
${ }^{1}$ Laboratoire de Botanique, Mycologie et Environnement, Faculté des Sciences, Université Mohammed V, Rabat, Morocco. Email: elrhzaouighita@gmail.com

${ }^{2}$ Departamento de Biología Vegetal II, Facultad de Farmacia, Universidad Complutense, E-28040, Madrid Spain. Email: amcrespo@ucm.es; pkdivaka@ucm.es
} 
ies as they can provide cost effective tools for mapping spatial and temporal patterns of atmospheric contamination (CONTI \& Cecchetti, 2001).

Moreover, lichens do not react only to a one pollutant but with combination of them, with good level of approximation (AMMAN \& al., 1987; CHETTRI \& al., 1997).This study was undertaken to determine background levels of elements by using Xanthoria parietina in a passive monitoring study. The ICP-AES has proved to be convenient technique for the determination of heavy metals accumulation (KAUPI \& al., 1992; MONACI \& al., 2000). Till time, no systematic data are available on atmospheric element concentrations and general information about air contamination in the target area is very few.

The second part of this work is about the detection of the metal rich particles on the thallus surface of the lichen. In previous studies, this has been directly detected by electron microscopy techniques (GARTY \& al., 1979; Olmez \& al., 1985; PuRvis \& al., 2000). The trapping of relatively large particles is the main cause of high metals contents in thalli that have been observed near industrial sites (SEAWARD, 1973; GARTY \& al., 1979).

A scanning electron microscope approach can perform the functions of imaging and elemental analysis, it is widely available and is comparatively rapid in that analysis and can be partially automated. Further, it characterizes physicochemical composition of the airborne particulate on biological material from multiple pollution sources (HAAPALA, 1998). The characterization of particulates on the lichen surface therefore offers a powerful complementary technique to whole -sample analysis.

\section{METHODS AND SAMPLING}

\section{FIELD SAMPLING}

The studied regions (Figure 1, Table 1) are located on the Atlantic coast between Kenitra and Mohammedia, Morocco. These sites are characterized by Mediterranean climate with an oceanic influence. They are highly susceptible to interference from the Atlantic Ocean during the rainy season. However, rainfall is very variable between the north and the south. The summer, on the other hand, is dry and sunny, but this does not preclude the appearance of banks of mist and dew, that are both quite common. During this period, annual rainfall is $60 \mathrm{~mm}$ in Kenitra, 560 $\mathrm{mm}$ in Rabat and $400 \mathrm{~mm}$ in Casablanca. In contrast, temperatures are rather homogeneous, with the Atlantic currents moderating the climate to give mild winters and summers. The average temperature in January is between $12-13^{\circ} \mathrm{C}$ while in summer it is around $23^{\circ} \mathrm{C}$. Dominant wind in these areas is the Gharbi wind oriented to the Ouest, with variations $(\mathrm{N} / \mathrm{W}, \mathrm{S} / \mathrm{W})$. Its impact is sometimes reinforced by the sea breeze with an average speed of $3 \mathrm{~m} / \mathrm{s}$.

Industries existing in the area studied are: paper industry, chemical, parachemical, petrochemical, thermic and metallurgic, and paper industry (according to regional investment centers of Kenitra, Rabat, and Mohammedia).

Specimens of Xanthoria parietina were sampled from nine sites, separated easily from the substrate by careful dissection of its basal organs. At each sites samples of Xanthoria were collected from at least three trees. The samples were pooled into one sample, with the help of knife and forceps; the samples were taken in polyethylen bags and transported to the laboratory in a clean environment. Care was taken to choose the thalli at a similar stage of development and only the outermost part of the thallus

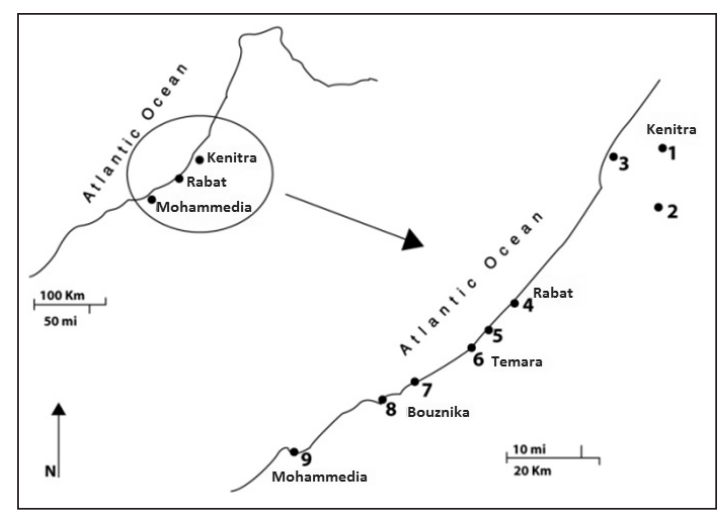

Figure 1. - Map of the study area showing the nine site locations sampled. See table 1 for information. 
Table 1

Sampling localities of Xanthoria parietina in Morocco

\begin{tabular}{llll}
\hline Site & Sampling location & latitude; longitude & Site description \\
\hline 1 & Forêt provinciale de Kenitra & $33.918392-6.977692$ & Forest (rural area) near road \\
2 & Forêt urbaine de Kenitra & $33.918292-6.977692$ & Forest (urban area) \\
3 & Forêt de Sidi Boughaba & $34.253527-6.677971$ & Forest (rural area) \\
4 & Forêt de Mkhinza & $34.022645-6.834269$ & Forest (urban area) \\
5 & Ceinture Verte de Temara & $33.93161-6.954045$ & Forest (rural area) \\
6 & CeintureVerte near Sidi Abed & $33.918684-6.976233$ & Forest (urban area) \\
7 & Skhirate & $33.830212-7.1206$ & Forest (urban area) \\
8 & Forêt de Bouznika & $33.783713-7.24411$ & Forest (rural area) \\
9 & Forêt de Mohammedia & $33.67864-7.385559$ & Forest (urban area) \\
\hline
\end{tabular}

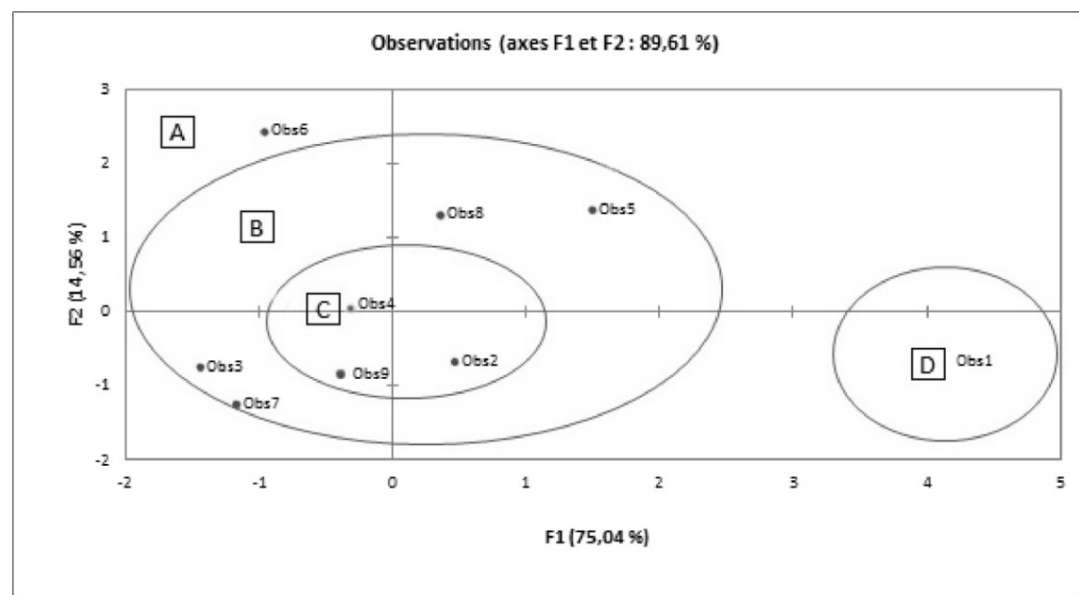

Figure 2. - PCA analysis of the nine sites studied.

about 2-3 mm length were considered for elemental analysis in order to reduce the within thallus variability in elements contents.

In the laboratory, samples were sorted to remove as much extraneous material (soil, particles, etc), with nylon tweezers under a binocular microscope (CONTI \& al., 2004).

\section{ANALYTICAL PROCEDURE ICP-AES}

For estimating concentrations of five heavy metals, lichens samples collected were washed thoroughly with desionised water for decontamination from the heavy metals deposited on the surface. Then lichen material was pulverised and ashed in glass vials at $550^{\circ} \mathrm{C}$ in a muffle furnace.
The resulting ash was digested in an acid mixture of $8 \mathrm{ml}$ of $65 \% \mathrm{HNO}_{3}, 2 \mathrm{ml}$ of $35 \% \mathrm{H}_{2} \mathrm{O}_{2}$ and 0.5 $\mathrm{ml}$ of $38-40 \% \mathrm{HF}$ of approximately $200 \mathrm{mg}$ dry weight in a microwave oven in preparation for analysis by ICP-AES. Concentrations of five elements were processed by multivariate statistical techniques in order to explore spatial trend in element bioaccumulation using XLSTAT 2015.

SEM

Preliminary SEM studies were necessary to establish the optimal operating conditions to obtain images of the thalli surfaces for subsequent image analysis (for the physical characterization of surface materials) and for elemental analysis. 
Systematic SEM studies of particulates on filters and other substrata commonly use automated imaging analysis in the SEM (WATT, 1998). This was inappropriate for lichen surfaces due to their complex topography and the difficulty in achieving consistent brightness contrast thresholds in back -scattered electron images.

The approach adopted here was to analyze everything on the thalli surfaces that constituted non -organic particulate or surface deposit materials.

Images were obtained for three randomly chosen areas on thalli from each of the 9 lichen stations and analysis were taken at $400 \mathrm{X}$ magnification in order to contain enough surface material to obtain a representative suite of analyses whilst adequate resolution were maintained to be able to characterize particulates $1 \mathrm{~mm}$ in diameter. The images were saved in Image (.jpg).

\section{StATISTICAL ANALYSIS}

Descriptive analysis in terms of means, minimum, maximum value and coefficient of variation $(\mathrm{CVs})$ were reported. Date were standardized and analyzed with multivariate techniques, such as cluster analysis (CA) and principal component analysis (PCA), these are considered statistical tools able to determine structures in the experimental data (TABACHNIK \& FIDELL, 1996; CONTI \& al., 2007; ZHOU \& al., 2007; CONTI \&
Mecozzi, 2008).

The PCA was applied using as variables the means of the concentrations to identify the unobservable, potential polluted sites and their elements characteristics.

\section{RESULTS AND DISCUSSION}

\section{ICP-AES PROCEDURE}

Results are summarized in tables 2, 3 and 4 . All the nine sites studied were grouped in four clusters in a dendrogram obtained by CA analysis (Figure 3).

\section{HEAVY METAL CONCENTRATIONS IN THE LICHEN THALLUS}

Results were highly significant $(\mathrm{p}<0.001)$. PCA analysis regrouped sites 4, 2 and 9 in one cluster; these sites have registered high concentrations of Fe and $\mathrm{Zn}$. Moreover, sites 3, 5, 7 and 8 belonged to area $\mathrm{B}$, these sites are located near rural areas, and higher and registered high accumulation of $\mathrm{Cu}$ were recorded especially from site 5 . The high accumulations of $\mathrm{Cu}$ in these areas are probably due to diesel engines as principal sources of contamination according to SEAWARD \& RICHARDSON (1989). This site has also registered high concentration of lead $42.05 \mu \mathrm{g} / \mathrm{g}$. Additionally high $\mathrm{Cr}$

\begin{tabular}{llllll}
\hline \multicolumn{5}{c}{ Mean concentration with SD of element analyzed (mg/Kg dry wet) } \\
\hline Sites & $\mathrm{Cr}$ & $\mathrm{Fe}$ & $\mathrm{Pb}$ & $\mathrm{Cu}$ \\
\hline 1 & $1242.326 \pm 40.34$ & $8422.018 \pm 12.428$ & $218.994 \pm 1.524$ & $22.822 \pm 1.430$ & $22.524 \pm 1.27$ \\
2 & $257.896 \pm 1.259$ & $3339.824 \pm 0.913$ & $121.673 \pm 0.841$ & $17.059 \pm 1.17$ & $7.955 \pm 0.48$ \\
3 & $74.983 \pm 0.111$ & $1974.961 \pm 0.566$ & $42.847 \pm 1.082$ & $2.852 \pm 0.104$ & $4.690 \pm 0.112$ \\
4 & $142.054 \pm 1.027$ & $1591.680 \pm 1.074$ & $38.349 \pm 1.178$ & $15.749 \pm 0.520$ & $4.065 \pm 0.573$ \\
5 & $183.385 \pm 1.198$ & $5744.538 \pm 1.278$ & $110.996 \pm 0.578$ & $42.05 \pm 1.025$ & $8.514 \pm 1.041$ \\
6 & $32.995 \pm 0.707$ & $851.343 \pm 0.852$ & $38.771 \pm 0.678$ & $7.22 \pm 0.781$ & $3.140 \pm 0.071$ \\
7 & $21.589 \pm 1.418$ & $1157.243 \pm 1.421$ & $25.087 \pm 1.356$ & $6.239 \pm 0.565$ & $4.612 \pm 0.678$ \\
8 & $68.151 \pm 2.121$ & $1872.033 \pm 20.324$ & $31.179 \pm 3.535$ & $22.634 \pm 1.060$ & $20.129 \pm 0.707$ \\
9 & $44.556 \pm 0.707$ & $479.976 \pm 1.414$ & $22.027 \pm 1.426$ & $5.231 \pm 1.237$ & $4.690 \pm 1.356$ \\
\hline
\end{tabular}


Table 3

Correlation matrix of Pearson. Asterics indicate levels of significance $(*, p<0.05 ; * *, p<0.01 ; * * *, p<0.001)$

\begin{tabular}{llllll}
\hline Pollutants & $\mathrm{Cr}$ & $\mathrm{Fe}$ & $\mathrm{Zn}$ & $\mathrm{Pb}$ & $\mathrm{Cu}$ \\
\hline $\mathrm{Cr}$ & 1 & 0.871 & $0.916^{* *}$ & 0.324 & $0.703^{*}$ \\
$\mathrm{Fe}$ & $0.871^{* *}$ & 1 & $0.953^{* * *}$ & $0.684^{*}$ & $0.665^{*}$ \\
$\mathrm{Zn}$ & $0.916^{* *}$ & $0.953^{* * *}$ & 1 & 0.530 & 0.616 \\
$\mathrm{~Pb}$ & 0.324 & 0.684 & 0.530 & 1 & 0.486 \\
$\mathrm{Cu}$ & $0.703^{*}$ & $0.665^{*}$ & 0.616 & 0.486 & 1 \\
\hline
\end{tabular}

Table 4

Percentage of heavy metals in superficial part of Xanthoria parietina thallus

\begin{tabular}{cccccc}
\hline & $\mathrm{Fe}(\%)$ & $\mathrm{Pb}(\%)$ & $\mathrm{Cr}(\%)$ & $\mathrm{Cu}(\%)$ & $\mathrm{Zn}(\%)$ \\
\hline 1 & 38,93 & 51,26 & 4,88 & 4,93 & 0 \\
2 & 31,52 & 25,45 & 3,66 & 20,22 & 19,17 \\
3 & 34,74 & 37,47 & 19,82 & 7,97 & 0 \\
4 & 51,78 & 17,97 & 3,75 & 10,34 & 16,13 \\
5 & 31,22 & 51,08 & 0 & 8,22 & 9,47 \\
6 & 23,31 & 37,2 & 7,64 & 18,03 & 13,81 \\
7 & 34,81 & 40,07 & 0 & 10,92 & 14,2 \\
8 & 33,53 & 34,37 & 2,3 & 13,68 & 16,12 \\
9 & 33,45 & 26,09 & 5,36 & 15,61 & 19,49 \\
\hline
\end{tabular}

concentration was reported in samples collected from site 1, area belonging to the cluster D, located near a road having heavy traffic activity according to NRIAGU \& PACYANA (1988). $\mathrm{Cr}$ is emitted in the atmosphere due to the coal and oil combustion, especially diesel-fed vehicles, refuse incineration.

In comparison with other heavy metals, iron is the most accumulated element in the Xanthoria thallus so far, the concentrations were between $8422.0188 \mathrm{mg} / \mathrm{kg}$ and 579.976 $\mathrm{mg} / \mathrm{kg}$. The site 1 located near a dusty road with a high traffic exhibits high concentration, followed by site 5 . Lichens also demonstrate specific affinity for Fe (PUCKETT \& al., 1976; GARTY \& DELAREA, 1991), the competitive uptakes studies revealed the selectivity sequence of different metals as $\mathrm{Fe}>\mathrm{Cr}>\mathrm{Zn}$. In this study, Xanthoria parietina shows similar selectivity sequences of metals as $\mathrm{Fe}>\mathrm{Cr}>\mathrm{Zn}>$ $\mathrm{Pb}>\mathrm{Cu}$. Acccording to GARTY \& al. (1979) iron is absorbed with very high amount in various lichens species and comparatively Xanthoria parietina accumulates significant amount of $\mathrm{Fe}$ $8422 \mathrm{mg} / \mathrm{Kg}$ of dry weight. It is applied as a construction material, also emitted from iron steel plants, and during the combustion of fossil fuels such as coal (FERNÁNDEZ \& al., 2000). It is among the major elemental constituents of soil minerals. However, high concentrations were also found in the site 5 .

The concentration of Zinc ranged from 218.995 to $2.027 \mathrm{mg} / \mathrm{kg}$. The higher concentration was registered in site 1 . The main source of Zinc is the automobile fuel, TAKALA \& OKKONEN (1981) correlated the Zn content of Hypogymnia physodes with traffic volume and similar results have also been observed in Diranaria papillufera (DUBEY \& al., 1999). Higher concentration of Zinc is also associated with automobile tire and incomplete combustion fuel GARTY (2001). Others anthropogenic emissions include pesticides, fertilizers, and coal burning power plants (SCERBO \& al., 2002).

The highest level of $\mathrm{Zn}$ found at site 1 is located near road with high traffic activities. 


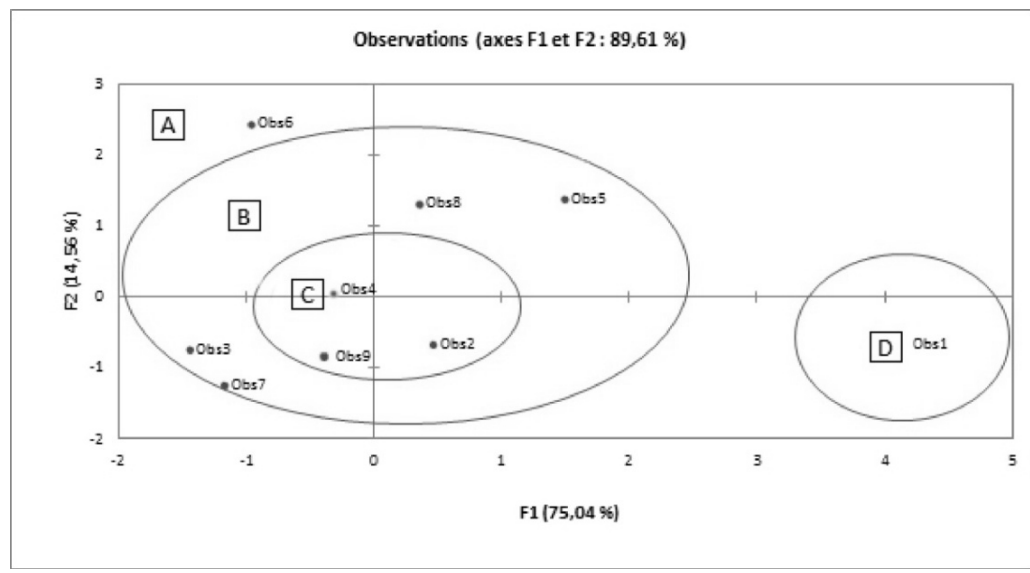

Figure 3. - Dendrogram of the hierarchical cluster analysis of the nine sites studied.

Concerning the lead, vehicle emissions have been the major source of $\mathrm{Pb}$, however due to the increased use of unleaded gasoline; the contribution of gasoline to atmospheric $\mathrm{Pb}$ is decreasing. Nonetheless combustion of coal and other petroleum products are now the principal sources of this toxic element in the environment. The high enrichment of $\mathrm{Pb}$ in site 5, suggests that the dominant source is non lithological, and that a variety of anthropogenic emissions contribute to their loading in the ambient air (SUZUKI, 2006). Further, a high concentration of $\mathrm{Pb}$ suggests combustion process caused by human activities (automobile, engine and metal smelting). In recent studies, the association of $\mathrm{Zn}, \mathrm{Pb}$ and $\mathrm{Ba}$ has been proposed as a reliable indicator of unleaded fuel and diesel oil powered motor vehicles (MONACI \& al., 2000). No statistical correlation between these two elements was found in the sites studied in this work.

$P$ value table shows strong correlation between $\mathrm{Fe}$ and $\mathrm{Zn}(\mathrm{p}<0.001)$, suggesting that probably $\mathrm{Fe}$ and $\mathrm{Zn}$ are coming from the same pollution source. According to GAO \& al. (2002), these elements are considered as indicators of anthropogenic emissions such as fossil fuel combustion and incineration along with emission from natural sources.

Summarizing, high concentration of heavy metals of $\mathrm{Fe}, \mathrm{Zn}, \mathrm{Cr}, \mathrm{Pb}$ and $\mathrm{Cu}$ are registered in site 1 in comparison with the other sites. It can be stated that Xanthoria as a bioacculumator associated to ICP-AES allows the monitoring of heavy elements in the environment.

\section{SEM ANALYSIS}

SEM-EDX is used to identify airborne particulate deposits and their distribution on biological materials from multiple pollution sources (HaApala, 1998). These heavy metals were detected in every sample of lichen analyzed. The most abundant chemical compositions found were $\mathrm{Fe}$ and $\mathrm{Pb}$. The SEM-EDX examination revealed that the whole sites contained high ratios of heavy metals $\mathrm{Fe}, \mathrm{Pb}, \mathrm{Cu}, \mathrm{Zn}$ and $\mathrm{Cr}$.

EDS spectra of samples in figure 5 analyzed has shown that almost all samples contains particles found naturally on the earth crusts like Si, $\mathrm{Al}, \mathrm{Fe}$ and $\mathrm{Ca}$. Samples from each forest sites revealed its accumulation of alumino silicate and Fe rich particles. Iron can be associated to fly ash pollution with other elements such as $\mathrm{Si}$ and $\mathrm{Al}$ (BoHM \& al., 1998; JALKANEN \& al., 2000). Fe rich particles contained also $\mathrm{Pb}$ in all sites analyzed indicating that these articles were derived from high combustion sources (EBERT \& al., 2004). $34 \%$ of the deposited particulates consisted of lead on site 1 and site 5, these results match with the ICP - AES analysis where the 
higher concentration has been registered in site 5 and site 1 .

According to High percentage of $\mathrm{Cu}$ was noticed in Xanthoria parietina's from site 2 with $20.22 \%$ and the low percentage in site $1(4.93 \%$ in Table 5). For zinc, the highest rate was noticed in site $9(19,49 \%)$ and site $2(19,17 \%)$. Moreover, chromium content was noticed in site 3 with a rate of $19.82 \%$ and the lower rate was registered $0 \%$ in site 7 and site 5 . Furthermore, the SEM analysis has also demonstrated that the ratio of Ca was high in certain site like site 6 and site 2. Calcium dioxide is a dominant alkaline component and, graph show that calcium is highly correlated $\mathrm{K}$ which is definitely the component of fly ash, and it suggests a local alkaline dust effect (GILBERT, 1976), probably coal combustion and road dust in this case. It can be explained by the vicinity of the forest sites with mains roads high traffic activities.

Observations by SEM from lichen are illustrated in Figure 4 the approach adopted here to analyze the thalli surface that constituted non organic particulate or surface deposit materials. Random areas were imaged initially at high magnification. All samples showed an agglomeration of irregular particles consisting mainly of inorganic amorphous constituents expected from the combustion of diesel and gasoline powered (Chaparro \& al., 2010), these finer and spherules grains were observed in forest sites near urban site (site 1 , site 2 , sites 4 , site 7 ). The samples also contain toxic elements as $\mathrm{Pb}$ and Zn, according to CHAPARRO \& al. (2002, 2006). Higher contents of these pollutants demonstrate that this contamination has an industrial origin. Further, high ratios of $\mathrm{Zn}$ are registered in site 2 and site 9, indicating that these particles are derived from high combustion sources (EBERT \& al., 2010). These sites belong to forest regions in urban area which are known by a high industrial activities and petroleum refinery. In addition, samples from polluted sites as site 1 , site 9 and site 5 exhibit agglomerates of micro sized and small particles and a predominance spherule and a variety of shapes. Most of these particles are iron oxide. These elements were reported by CHAPARRO \& al. (2010) as being from vehicle pollution.

\section{CONCLUSION}

Our results indicate that the exhaust gases of motor vehicles and other anthropogenic activities are the main sources of air pollution in forest ecosystem analyzed. SEM-EDX and ICP-AES has revealed information about chemical deposition of air borne particulate accumulated on epiphytic lichens. With the results at hand, it was possible to evaluate emission sources allowing the qualitative analysis of the forest sites studied.

Furthermore, the present study demonstrated that lichens could be used to determine heavy metals in dry and warm climate in Morocco; the lichen accumulates high amounts of heavy metals. This result could be considered as a baseline data for further continuous research work related with biomonitoring and assessment of air quality in the forest sites studied. Additionally, cluster analysis revealed elements as indicative of different local sources or source regions. Our results indicate that the concentrations of $\mathrm{Fe}$ and $\mathrm{Pb}$ originated mostly from iron-steel works of industrial region. For Fe, the soil dust could also be an important contamination source. The Traffic emissions were resulted the main contributor for $\mathrm{Pb}$ contamination. The concentrations of elements and $\mathrm{Pb}$ were very high in forest site near urban areas reflecting the effects of both urbanization and industrial activities, mostly due to coal combustion. 

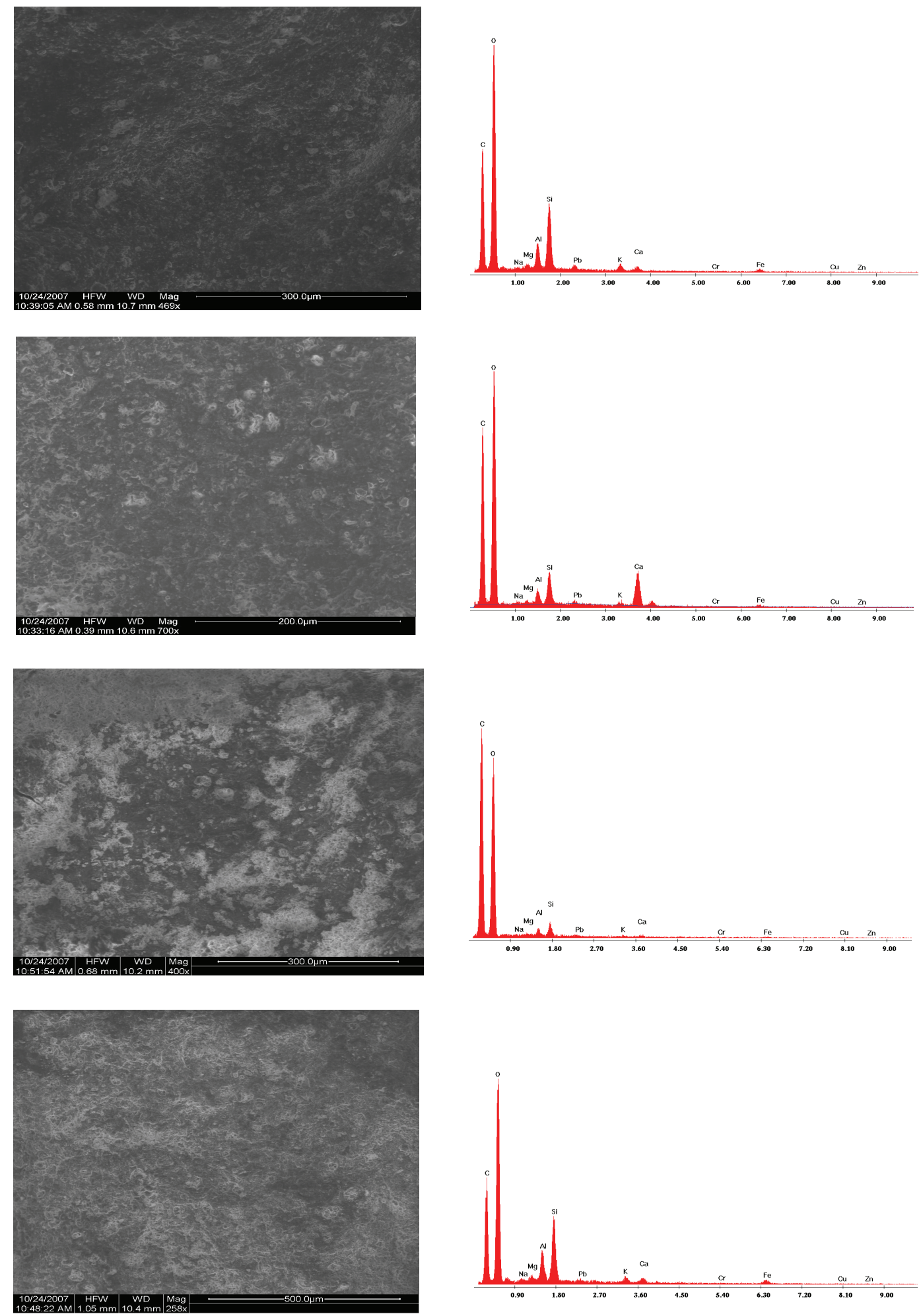

Figure 4. - Scanning electron micrographs and EDS spectra showing particulate matter of superficial part of Xanthoria parietina of the nine sites studied (up to bottom). 

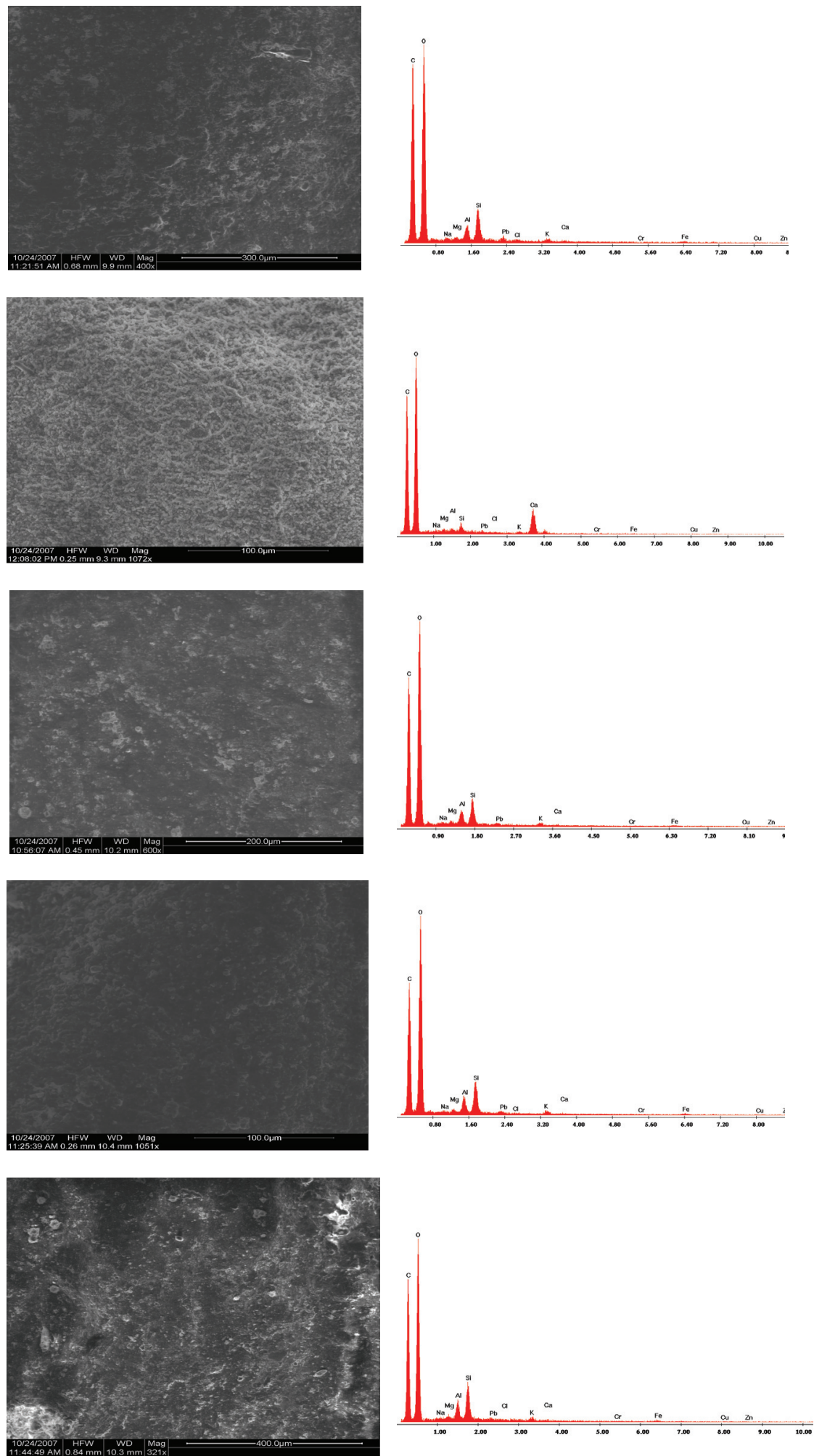

Figure 4. - (Continuación) 


\section{REFERENCES}

Amman, K., Herzig, R., Liebendörfer, L. \& Urech, M. 1987- Multivariate correlation of deposition data of 8 different air pollutants to lichen data in a small town in Switzerland - Adv. Aerobiol. 87: 40-406.

Böhm, Ch.O. - 1998 - Geology of the Natawahunan Lake area (parts of NTS 63P/11) — Manitoba Energy and Mines, Minerals Div. Prelim. Map 1:50.000.

Chaparro, M.A.E., Marié, D.C., Gogorca, C.S.G., Navas, A. \& Sinitio, A.M. - 2010 - Magnetic studies and scanning electron microscopy-X-ray energy dispersive spectroscopy analyses of roads sediments, sols and vehicle derived emissions - Stud. Geophys. Geod. 54 (4): 663 -650.

Chaparro, M.A.E., Gogorza, C.S.G., Chaparro, M.A.E., Irurzun, M.A., \& Sinito, A.M. -2006- Review of magnetism and pollution studies of various environments in Argentina — Earth Planets Space 58(10):1411-1422.

Chettri, M.K., Sawidis, T. \& Karataglis, S. -1997Lichens as a tool for biogeochemical prespecting Ecotox. Environ. Safe. 38 (3): 322 -335.

Conti, M.E., Cucina, D. \& Mecozzi, M. -2008Regression analysis model applied to biomonitoring studies — Environ. Model. Assess. 13: 553-565.

Conti, M.E. -2008 - Biological monitoring: theory and applications (The Sustanaible World). Billerica - WIT Press, Sienna. 227 pp.

Conti, M.E., Iacobucci, M. \& Cecchetti, G. —2007- A biomonitoring study: trace metals in seagrass, algae and molluscs in a marine reference ecosystem (southern Tyrrhenian Sea) - Int. J. Environ. Pollut. 29 (1-3): 308332.

Conti, M.E., Tudino, M., Stripeikis, J. \& Cecchetti, G. 2004 - Heavy metal accumulation in the lichen Evernia prunastri transplanted at urban, rural and industrial sites in central Italy — J. Atmos. Chem. 49: 83-94.

Conti, M.E. \& Cecchetti, G. - 2001- Biological monitoring: lichens as bioindicators of air pollution assessment A review - Environ. Pollut 114: 471-492.

Dubey, A.N., Pandey, V., Upreti, D.K. \& Singh, J. 1999 - Accumulation of lead by lichens growing in and around Faizabad, U.P. — India J. Environ. Biol. 20 (3): 223-225.

Ebert, M., Weinbrunch, S., Hoffman, P. \& Ortner, H.M. 2004 - Chemical composition and complex refractive index of rural and urban influenced aerosols determined by individual particle analysis - Atmos. Environ. 36: 773-780.

Fernández-Valmayor, A., Lopez-Alonso, C., Sere, A. \& Fernández-Manjon, B. - 1999 - The Design of a Flexible Hypermedia System: Integrating an interactive learning paradigm for Foreing Language Text Comprehension - In: Franklin, S.D. \& Strenski, E. (Eds.). Building University Electronic Educational Environments. Pp. 51-66. Kluwer Acad. Publ., Boston.

Gao, Y., Nelson, E.D., Field, M.P., Ding, Q., Li, H., Sherrell, R.M., Gigliotti, C.L.,Van, D.A., Glenn, T.R. \& Eisenreich,
S.J. - 2002 - Characterization of atmospheric trace elements on PM2.5 particulate matter over the York-New Jersey harbor estuary — Atmos. Environ. 36: 1077-1086.

Garty, J. - 2001 - Biomonitoring atmospheric heavy metals with metals with lichens: Theory and application. Crit — Rev. Plant Sci. 20:309-371.

Garty, J. \& Delarea, J. - 1991 - Localization of iron and other elements in the lichen Nephromaarcticum (L.) Torss - Environ. Exp. Bot. 31: 36-375.

Garty, J., Galun, M. \& Kessel, M. —1979— Localization of heavy metals and other elements accumulated in the lichen thallus — New Phytol. 82: 159-68.

Gilbert, O.L. - 1976 - An alkaline dust effect on epiphytic lichen - Lichenologist 8: 173-178.

Haapala, A., Muotka, T. -1998 - Seasonal dynamics of detritus and associated macro invertebrates in a channelized boreal stream - Archiv. Hydrobiol. 142: 171-189.

Jalkanen,T., Makinen, A., Hasanen, E. \& Juhanoja, J. 2000 - The effect of large anthropogenic particulate emissions on atmospheric aerosols, deposition and bioindicators in the eastern Gulf of Finland region Sci. Total Environ. 262: 123-136.

Kaupi, M. \& Halonen, P. —1999- Lichens as bioindicators of air pollution in Oulou, northen Finland - Ann. Bot. Fenn. 29: 1-9.

Markert, B. - 1996 - Instrumental element and multi-element analysis of plant samples. Methods and applications - John Wiley, Chichester. 296 pp.

Monaci, F., Lanciotti, E., Grechi, D. \& Bargagli, R. 2000 - Biomonitoring of airborne metals in urban environments: new tracers of vehicle emission, in place of lead - Environ. Poll.107: 321-327.

Olmez, I., Gulovali, M. \& Gordon, G. -1985- Trace elements concentrations in lichens near a coal-fired power plant - Atmos. Environ. 10: 1663-1669.

Puckett, K. J. - 1976 - The effect of heavy metals on some aspects of lichen physiology - Can. J. Bot. 54: 26952703.

Purvis, O.W., Williamson, B.J., Bartok, K. \& Zoltani, N. 2000 - Bioaccumulation of lead by the lichen Acarospora smaragdulasens Lat. from smelter emissions in the town of Zlatna, Romania — New Phytol. 147: 591-599.

Scerbo, R., Ristori T., Possenti L., Lampugnani L., Barale, R. \& Barghigiani, C. - 2002- Lichen (Xanthoria parietina) biomonitoring of trace element contamination and air quality assessment in Pisa Province (Tuscany, Italy) — Sci. Total Environ. 286: 27-40.

Seaward, M.R.D. \& Richardson, D.H.S. -1998Atmospheric sources of metal pollution and effect on vegetation - In: Shaw, A.J. (Ed.). Heavy metal tolerance in plants: Evolutionary aspects. Pp. 5-92. CRC Press, Boca Raton.

Seaward, M.R.D. - 1973 - Lichen ecology of the Scunthorpe heathlands, I. Mineral accumulation Lichenologist 5: 423-33. 
Suzuki, N., Murakami, K., Takeyama, H. \& Chow, S. 2006- Molecular attempt to indentify prey organisms of lobster pyllosoma larvae — Fish. Sci. 72: 342 -349.

Tabachnick, B.G. \& Fidell, L.S. —1996 - Using multivariate statistics, 3rd ed. - Harper Collins, New York.

Wilkinson, L. \& Task Force Stat. Inf. — 1999— Statistical methods in psychology journals: Guidelines and explanations - Am. Psychol. 54: 594-604.

Takala, K. \& Okkonen, H. -1981- Lead content of an epiphytic lichen in the urban area of Kuopio, east central Finland - Ann. Bot. Fenn.18: 85-89.
Tyler, G. - 1989 - Uptake, retention, and toxicity of heavy metals in lichens: a brief review - Water Air Soil Pollut. 47: 321-333.

Watt, J. - 1998 - Automated characterization of individual carbonaceous fly ash particles review of alternative techniques - Water Air Soil Pollut. 106: 309327.

Zhou, I., Dikinson, R.E., Tian, Y., Vose, R. \& Dai, Y. 2007- Impact of vegetation removal and soil radiation on diurnal temperature range in a semiarid region application to the Sahel — Proc. Nat. Acad. Sci. USA. 104 (46): 1793-1794.

Received: 22 June 2015

Accepted: 24 September 2015 